\title{
ADAPTASI PERUBAHAN IKLIM DAN KETAHANAN PANGAN: TELAAH INISIATIF DAN KEBIJAKAN
}

\author{
Perdinan ${ }^{191}$, Tri Atmaja192, Ryco F. Adi² dan Woro Estiningtyas ${ }^{193}$
}

\begin{abstract}
Abstrak
Dalam dua dekade terakhir, berbagai program intensifikasi penggunaan sarana produksi pertanian (misal: bantuan benih, pupuk bersubsidi, pupuk organik, dan perbaikan irigasi) telah berdampak terhadap peningkatan produksi beras nasional. Di balik keberhasilan program tersebut, fluktuasi kondisi iklim memberikan tantangan dalam mempertahankan stabilitas produksi nasional. Kondisi tersebut dapat diperparah dengan adanya potensi dampak negatif perubahan iklim yang berakibat pada penurunan produktivitas ataupun peningkatan serangan hama dan penyakit. Ancaman lainnya adalah peningkatan fenomena iklim ekstrem yang dapat menyebabkan bencana banjir dan kekeringan, sehingga berimplikasi pada gagal panen ataupun gagal tanam. Memperhatikan kondisi tersebut, tulisan ini membahas berbagai inisiatif adaptasi yang dilakukan melalui langkah praktis dan didorong oleh regulasi yang dikeluarkan pemerintah Indonesia. Praktik adaptasi dilakukan melalui insiatif mandiri berdasarkan kearifan lokal maupun bantuan pemerintah. Iniastif pemerintah terkait adaptasi dilakukan melalui Pedoman Umum Langkah-Langkah Adaptasi Perubahan Iklim (Pedum) dan langkah praktis dalam strategi budidaya yang responsif terhadap perubahan iklim.
\end{abstract}

Kata Kunci: Perubahan Iklim, Ketahanan Pangan, Adaptasi, Padi

\begin{abstract}
In the last two decades, programs on intensifying the use of agricultural inputs (e.g. seed support, subsidized fertilizer, organic fertilizer, and irrigation improvement) have increased national rice production. Apart from the success of the programs, fluctuations in climatic conditions present challenges in maintaining national production stability. These conditions can be exacerbated by the potential negative impacts of climate change, which may decrease crop productivity or increase pest and disease attacks. Another threat is the escalation of extreme climate events that can lead to climatic hazards such as flood and drought, resulting in crop damage or crop failure. Considering the climatic impacts, this paper discusses various adaptation initiatives undertaken through practical measures and regulations issued by the Indonesian government. The adaptation practices are done through independent initiatives based on local wisdom as well as government assistance. The government initiatives on
\end{abstract}

191 Penulis adalah dosen dan peneliti pada Departemen Geofisika dan Meteorologi, Institut Pertanian Bogor.

192 Penulis adalah peneliti pada PIAREA.

193 Penulis adalah peneliti pada Balai Besar Penelitian dan Pengembangan Sumber daya Lahan Pertanian. 
adaptation are endorsed through the Guidelines for Climate Change Adaptation Measures (Pedum) and Practical Steps related to climate responsive farming.

Keywords: Climate Change, Food Security, Adaptation, Rice

\section{Pendahuluan}

Pemenuhan suplai bahan pangan utama sangat penting dalam menjaga stabilitas suatu negara. Mengacu pada dokumen Rencana Pembangunan Pertanian Indonesia 2015-2019, beras merupakan makanan pokok bagi sebagian besar (> 95\%) penduduk Indonesia. Sebagai bahan makanan utama, beras memainkan peran penting dalam perekonomian dan pembangunan nasional. Beras penting untuk perekonomian Indonesia dengan pertimbangan: (1) sistem agrobisnis padi memperkuat ketahanan pangan nasional; (2) kegiatan pertanian padi dan kontributor utama sistem pertanian nasional padat karya; dan (3) banyak petani padi masih dianggap miskin dan dengan demikian sensitif terhadap kerugian produksi. ${ }^{194}$
Sektor pertanian pada 5 (lima) tahun terakhir (2015-2019) mengacu pada Paradigma Pertanian untuk Pembangunan (Agriculture for Development) yang memosisikan sektor pertanian sebagai penggerak transformasi pembangunan yang berimbang dan menyeluruh mencakup transformasi demografi, ekonomi, antar-sektoral, spasial, institusional, dan tata kelola pembangunan. Paradigma tersebut memberikan arahan bahwa sektor pertanian mencakup berbagai kepentingan yang luas dan multifungsi. Selain sebagai sektor utama tumpuan ketahanan pangan, sektor pertanian memiliki fungsi strategis lainnya termasuk untuk menyelesaikan persoalanpersoalan lingkungan dan sosial (kemiskinan, keadilan, dan lain-lain)

194 P. Simatupang dan I.W. Rusastra, “Kebijakan Pembangunan Sistem Agribisnis Padi dalam Ekonomi Padi dan Beras Indonesia", Jakarta: Badan Penelitian dan Pengembangan Pertanian, Departemen Pertanian, 2004), hlm. 31-52. 
serta penyedia sarana wisata (agrowisata).

\section{Mempertimbangkan posisi}

strategis beras dalam pembangunan nasional Indonesia dan paradigma sektor pertanian ke depan, produksi padi nasional mendapatkan perhatian besar dari pemerintah Indonesia. Berdasarkan laporan Badan Pusat Statistik (BPS), pada tahun 2017 produksi beras nasional mencapai 81,38 juta ton Gabah Kering Giling (GKG). Produksi tersebut lebih besar dibandingkan dekade sebelumnya yaitu sebesar 57,15 juta ton GKG pada tahun 2007. Peningkatan produksi beras nasional tersebut diindikasikan sebagai keberhasilan program intensifikasi pertanian yang terkait dengan peningkatan penggunaan sarana produksi pertanian (misal: bantuan benih, pupuk bersubsidi, pupuk organik, dan perbaikan irigasi). ${ }^{195}$ Di balik keberhasilan inovasi teknologi pertanian tersebut, fluktuasi kondisi iklim, khususnya kejadian iklim ekstrem, memberikan sebuah tantangan dalam menjaga stabilitas produksi padi nasional. Pertumbuhan dan perkembangan padi yang berimplikasi pada produksi padi juga dipengaruhi oleh variabilitas iklim. ${ }^{196}$

Perubahan iklim global berdampak nyata pada produksi tanaman pangan. Secara global, perubahan iklim diproyeksikan dapat menurunkan produksi tanaman, terutama di wilayah pertanian yang terletak di lintang rendah akan mengalami dampak negatif.197 Dampak negatif tersebut dikarenakan wilayah lintang rendah memiliki suhu udara yang berada pada

195 Purdiyanti Pratiwi, “Efektivitas dan Perumusan Strategi Kebijakan Beras Nasional”, (Bogor: Departemen Agribisnis, Institut Pertanian Bogor, 2008), hlm. 61-158.

${ }^{196}$ Gerrit Hoogenboom, "Contribution of Agrometeorology to The Simulation of Crop Production and Its Applications", Agricultural and Forest Meteorology 103, No. 1-2 (2000): hlm. 137-157, lihat juga Raymond P. Motha and Wolfgang Baier, "Impacts of Present and Future Climate Change and Climate Variability on Agriculture in The Temperate Regions: North America", Climatic Change 70, No. 1-2 (2005), hlm. 137-164, dan llihat F. N. Tubiello, J.-F. Soussana and S. M. Howden, "Crop and Pasture Response to Climate Change", Proceedings of The National Academy of Sciences 104, No. 50 (2007), hlm. 19686-19690.

${ }^{197}$ William Cline, "Global Warming and Agriculture: Impact Estimates by Country," Choice Reviews Online 45, No. 04 (2007), hlm. 97-98. 
batas toleransi tanaman (di bawah $10^{\circ} \mathrm{C}$ dan di atas $\left.29^{\circ} \mathrm{C}\right) .{ }^{198}$

Berdasarkan simulasi model tanaman, dilaporkan bahwa kenaikan suhu $1^{\circ} \mathrm{C}$ dan kenaikan curah hujan $5 \%$ akan menurunkan produktivitas padi hingga 0,33 ton/ha. ${ }^{199}$ Sementara itu, kejadian iklim ekstrem yang seringkali berakibat pada kejadian banjir dan kekeringan di Indonesia juga berdampak negatif terhadap produksi tanaman pangan. Proyeksi pemanasan global dapat meningkatkan frekuensi kejadian El Niño-Southern Oscillation (ENSO) yang ditandai dengan kejadian El Niño dan La Niña. El Nino merupakan kejadian dimana musim panas yang relatif lebih panjang sehingga berimplikasi pada kejadian kekeringan, sementara La Nina ditandai dengan intensitas curah hujan tinggi yang berdampak pada banjir. 200

Memahami potensi dampak perubahan iklim diperlukan langkah antisipasi atau dikenal dengan istilah adaptasi perubahan iklim. Adaptasi perubahan iklim diarahkan untuk memanfaatkan dampak positif dan meminimimalkan dampak negatif perubahan iklim. Kegiatan adaptasi dapat dilakukan melalui perbaikan insfrastruktur maupun melalui pengembangan kapasitas petani dan komoditas. Khusus sektor pertanian, pemerintah Indonesia telah menyusun langkah dan strategi adaptasi perubahan iklim untuk pengembangan pertanian terhadap dampak perubahan iklim dalam Pedoman Umum Adaptasi Perubahan Iklim (Pedum) yang diterbitkan pada 2011 oleh Kementerian Pertanian. Tulisan ini akan membahas mengenai dampak perubahan iklim terhadap produksi tanaman pangan dengan fokus komoditas beras, serta inisiatif strategi adaptasi perubahan iklim dan 58-61.

198 G. S. L. H. V Prasada Rao, Agricultural Meteorology (Thrissur: PHI Learning Pvt. Ltd, 2008), hlm.

199 Peter Rene Hosang, J. Tatuh, dan Johannes E. X. Rogi, “Analisis Dampak Perubahan Iklim Terhadap Produksi Beras Provinsi Sulawesi Utara Tahun 2013-2030,” Jurnal Eugenia 18, No. 3 (2012), hlm. 249-256.

200 A. Timmermann et al., "Increased El Niño Frequency in A Climate Model Forced by Future Greenhouse Warming", Nature 398, no. 6729 (1999): hlm. 694-697. 
kebijakan pendukung implementasi upaya adaptasi di Indonesia. ${ }^{201}$

Metode yang digunakan dalam penulisan ini adalah desk study dengan melakukan pengumpulan data dan informasi terkait dengan penelitian di bidang tanaman padi, perubahan iklim, dan kebijakan terkait pertanian dan perubahan iklim. Analisis terhadap data sekunder terkait sektor beras dalam lingkup nasional juga dilakukan untuk memperkuat hasil telaah berbagai dokumen terkait kebijakan dan program peningkatan produksi beras nasional. Hasil tulisan diharapkan dapat menjadi salah satu referensi terkait informasi adaptasi perubahan iklim sektor tanaman padi

\section{Distribusi Sentra Produksi Padi dan Rantai Pasok Beras}

Merujuk data luas panen padi nasional yang dikeluarkan BPS tahun 2015, wilayah Jawa Timur, Jawa Tengah, dan Jawa Barat memiliki luas panen terbesar untuk produksi padi di Indonesia (Gambar 1). Luas panen total tahun 2015 berturut-turut adalah 2,15 juta/ha, 1,88 juta/ha dan 1,86 juta/ha, setara sekitar $15,2 \%, 13,3 \%$, dan 13,2\% dari luas panen padi nasional. Sentra produksi padi di Jawa Timur adalah Jember, Cilacap untuk Jawa Tengah, sementara Indramayu adalah daerah produksi utama padi di Jawa Barat. sejalan dengan upaya ketahanan pangan nasional.
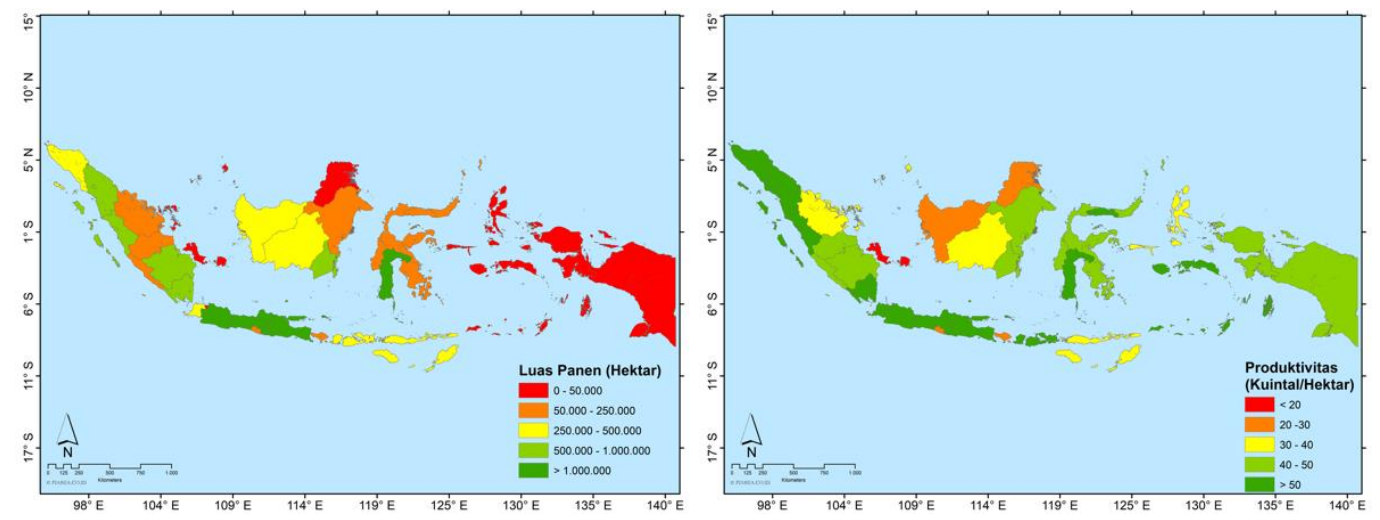

${ }^{201}$ Naskah disampaikan pada Lokakarya dan Seminar Nasional Adaptasi dan Mitigasi Perubahan Iklim, Bogor, 13-14 September 2017. 


\section{Gambar 1. Luas Panen (Kiri) dan Distribusi Spasial Produktivitas (Kanan) Padi di Indonesia Tahun $2015^{202}$}

Berdasarkan wilayah sebaran, mayoritas daerah pertanaman padi tumbuh pada tipe iklim monsun terutama di Pulau Jawa (Gambar 1). Jenis iklim dan tanah wilayah tersebut cocok untuk pertumbuhan dan perkembangan padi. Wilayah pulau Jawa, termasuk di dalamnya Provinsi Jawa Timur, Jawa Tengah, dan Jawa Barat, merupakan wilayah yang berkontribusi paling banyak dalam produksi nasional, yaitu sebanyak 36 juta ton atau sekitar 52,9\%. Kemudian disusul oleh produksi dari Pulau Sumatera yang memiliki produksi padi antara 1 sampai 4 juta ton. Produksi dari Pulau Kalimantan menempati posisi ketiga, yakni dengan tingkat produksi sebesar 0,5 sampai 2 juta ton. Sedangkan, Pulau Sulawesi berada di posisi keempat karena memiliki tingkat produksi padi relatif bervariasi. Terakhir, produksi padi terendah berada di wilayah Indonesia Timur khususnya wilayah Papua (Gambar 1).

Walaupun demikian, padi yang diproduksi oleh petani secara umum tidak dapat langsung diakses oleh konsumen terakhir. Hal ini karena sistem distribusi yang dikenal dengan sebutan rantai pasok, membuat beberapa jalur rantai untuk mendistribusikan hasil panen padi dari petani untuk sampai kepada konsumen (Gambar 2).

Secara umum, padi yang dipanen petani akan melewati kegiatan pasca panen seperti pengeringan dan penggilingan untuk menghasilkan beras. Beras tersebut kemudian disimpan untuk dijual melalui supermarket atau pedagang besar yang menjual beras ke pengecer atau pasar tradisional kecil. Jalur lainnya, pabrikpabrik kecil yang memproses padi menjadi beras mengirimkan beras ke Koperasi Unit Desa (KUD) atau unit

202 Badan Pusat Statistik (BPS), "Tanaman Padi Per Provinsi", https://www.bps.go.id/site/resultTab, diakses 3 September 2018. 
usaha yang dimiliki masyarakat yang kemudian mengirimkan beras ke Badan Urusan Logistik (Bulog). Bulog merupakan perusahaan milik negara yang dapat menjual beras dengan harga lebih rendah untuk keperluan rumah tangga, terutama kepada yang kurang mampu, melalui program distribusi beras yang disebut Beras Sejahtera (Rastera). Upaya ini menunjukkan komitmen pemerintah untuk membantu petani dan rumah tangga mengakses makanan pokok dan menjaga ketahanan pangan.
Saat ini dengan berkembangnya teknologi informasi dan transportasi, para pelaku dalam rantai pasok dapat berkoordinasi untuk meningkatkan kinerja distribusi beras di Indonesia. Dengan rantai pemasaran dipersingkat dan perbaikan fasilitas yang sesuai, biaya transaksi dapat dikurangi. Sebagai contoh, perbaikan dalam teknologi komunikasi dapat mempermudah koordinasi, sehingga menghemat waktu. Perbaikan sarana transportasi dapat meningkatkan efektivitas distribusi beras dari satu daerah ke daerah lain.

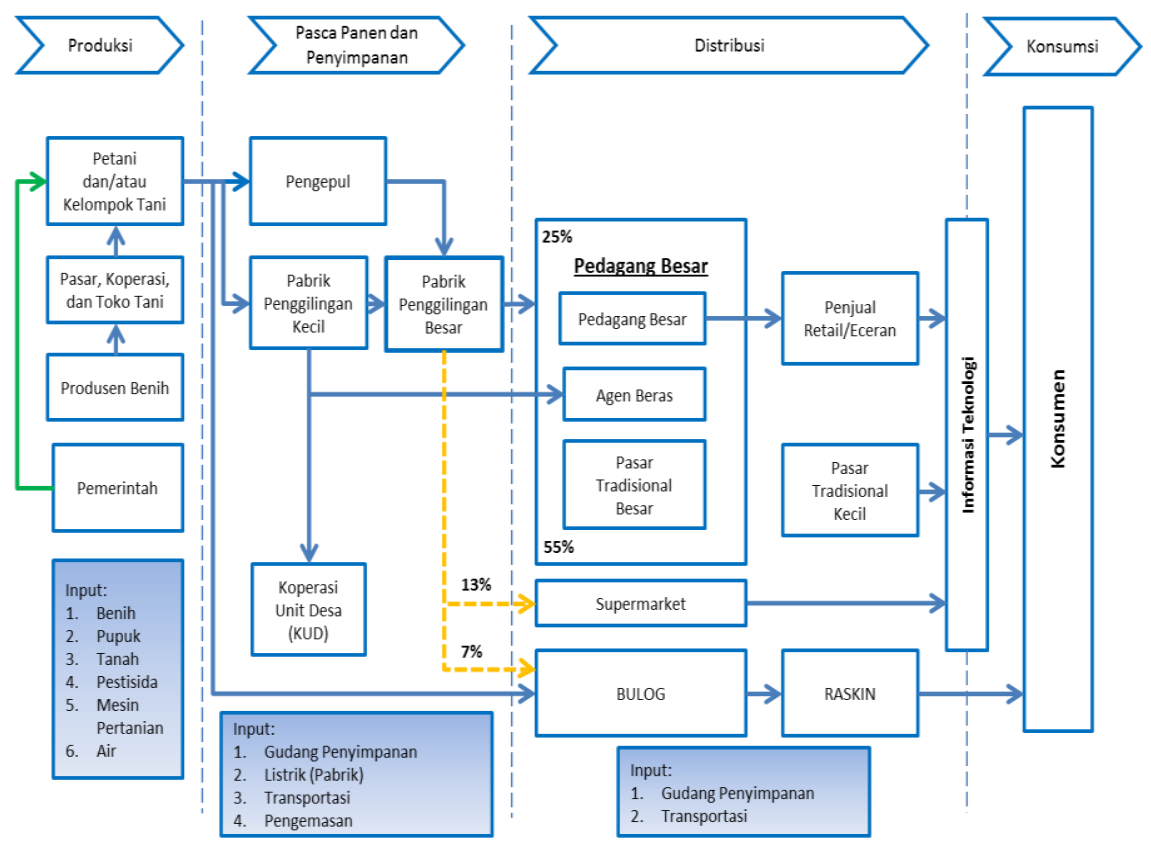

Gambar 2. Jaringan Suplai Beras di Indonesia ${ }^{203}$

${ }^{203}$ Disarikan berdasarkan hasil rekapitulasi dari berbagai sumber 
III. Produksi dan Kebutuhan Padi Nasional

Selama periode 1993 - 2013, terjadi peningkatan produksi padi dari 48,1 juta ton Gabah Kering Giling (GKG) pada tahun 1993 menjadi 71,3 juta ton GKG pada tahun 2013.204 Dengan menggunakan faktor konversi GKG ke beras sebesar 0,62, produksi beras nasional disajikan pada Gambar 3.

Total produksi tahunan cukup fluktuatif dengan terjadinya penurunan produksi pada tahun-tahun tertentu (1993, 1996, 2000, 2005, 2010). Penurunan tersebut diidentifikasi terkait dengan kejadian fenomena ENSO yang berdampak pada kejadian iklim ekstrem pemicu kejadian banjir dan kekeringan di Indonesia. Walaupun demikian, secara keseluruhan produksi beras tahunan nasional menunjukkan tendensi adanya peningkatan dari tahun ke tahun, dengan peningkatan cukup besar terjadi pada tahun 2006 - 2008.

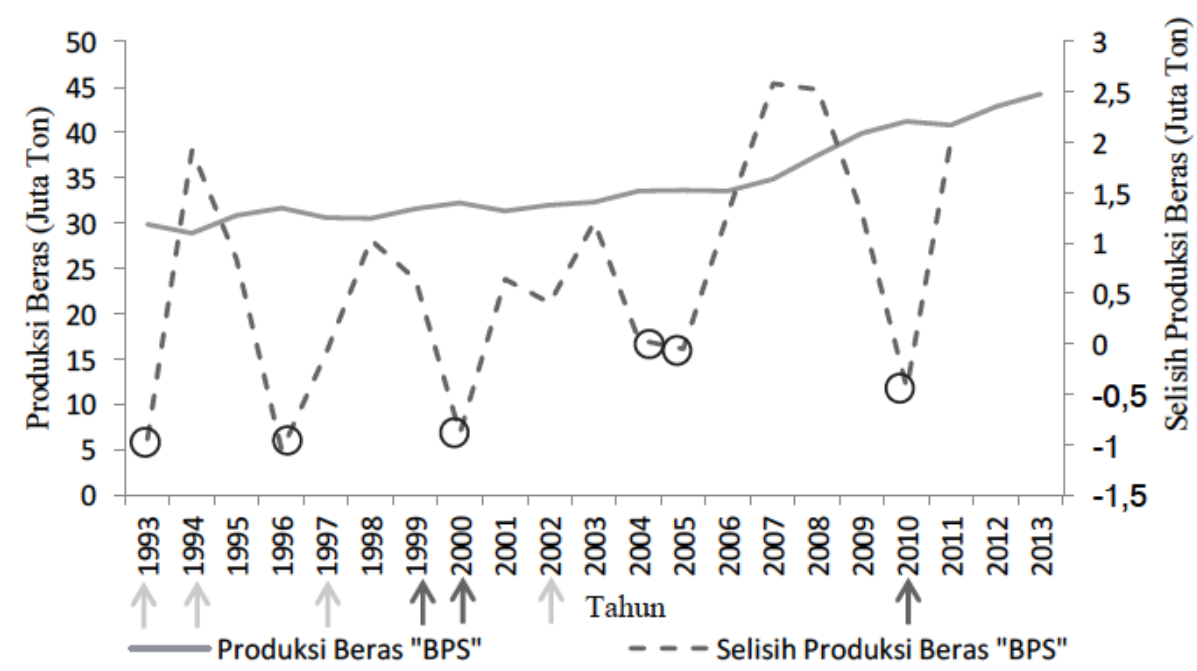

Gambar 3. Produksi Beras Nasional. $\uparrow$ Tahun El-Nino, $\uparrow$ Tahun La-Nina. Selisih Produksi Beras Adalah Perbedaan Produksi Tahun Berjalan Dengan Tahun Sebelumnya ${ }^{205}$ 
Jika dibandingkan dengan negaranegara Asia lain yang mengkonsumsi beras sebagai makanan pokoknya, maka konsumsi beras di Indonesia termasuk dalam kategori tinggi. Hal ini dapat dilihat melalui Survei Sosial Ekonomi Nasional yang dilakukan oleh BPS pada tahun 2015. Survei tersebut menyebutkan bahwa konsumsi beras per kapita per Maret 2015 adalah sebesar 98 kilogram per tahun. Jumlah ini meningkat dibanding tahun sebelumnya yang hanya 97,2 kg per tahun.

Dengan tingkat konsumsi rata-rata sekitar 98 kilogram per kapita per tahun (kg/kapita/tahun), Indonesia melampaui Malaysia kg/kapita/tahun), Thailand (70 $\mathrm{kg} /$ kapita/tahun), Jepang (50 $\mathrm{kg} /$ kapita/tahun), dan Korea (40 kg/kapita/tahun). ${ }^{206}$ Lebih lanjut, estimasi pemenuhan kebutuhan beras nasional, dengan menggunakan asumsi tingkat konsumsi beras, yaitu: 139 kilogram per kapita per tahun (kg/kapita/tahun), 130 kilogram per kapita per tahun (kg/kapita/tahun), 120 kilogram per kapita per tahun (kg/kapita/tahun), 113 kilogram per kapita per tahun (kg/kapita/tahun) dan 114,6 kilogram per kapita per tahun ( $\mathrm{kg} / \mathrm{kapita} /$ tahun) untuk tahun 2017 dan 2018,207 produksi padi nasional diperkirakan tetap masih mencukupi kebutuhan (konsumsi) nasional atau dengan kata lain Indonesia masih mengalami 'surplus' beras.

Analisis surplus beras dilakukan dengan cara mengurangi estimasi total produksi beras dengan total konsumsi beras nasional. Perbedaan nilai surplus beras dikarenakan perbedaan asumsi tingkat konsumsi per-kapita. ${ }^{208}$ Berikut estimasi nilai surplus dapat dilihat pada Gambar 4.

206 Ibid.

${ }^{207}$ Kementan, “Buletin Konsumsi Pangan,” Vol. 9 No. 1 Tahun 2018, hlm. 11-19.

208 Popi Rejekiningrum, Model Optimasi Surplus Beras Untuk Menentukan Tingkat Ketahanan Pangan Nasional, (Jakarta: Universitas Terbuka, 2013), hlm. 1-14. 


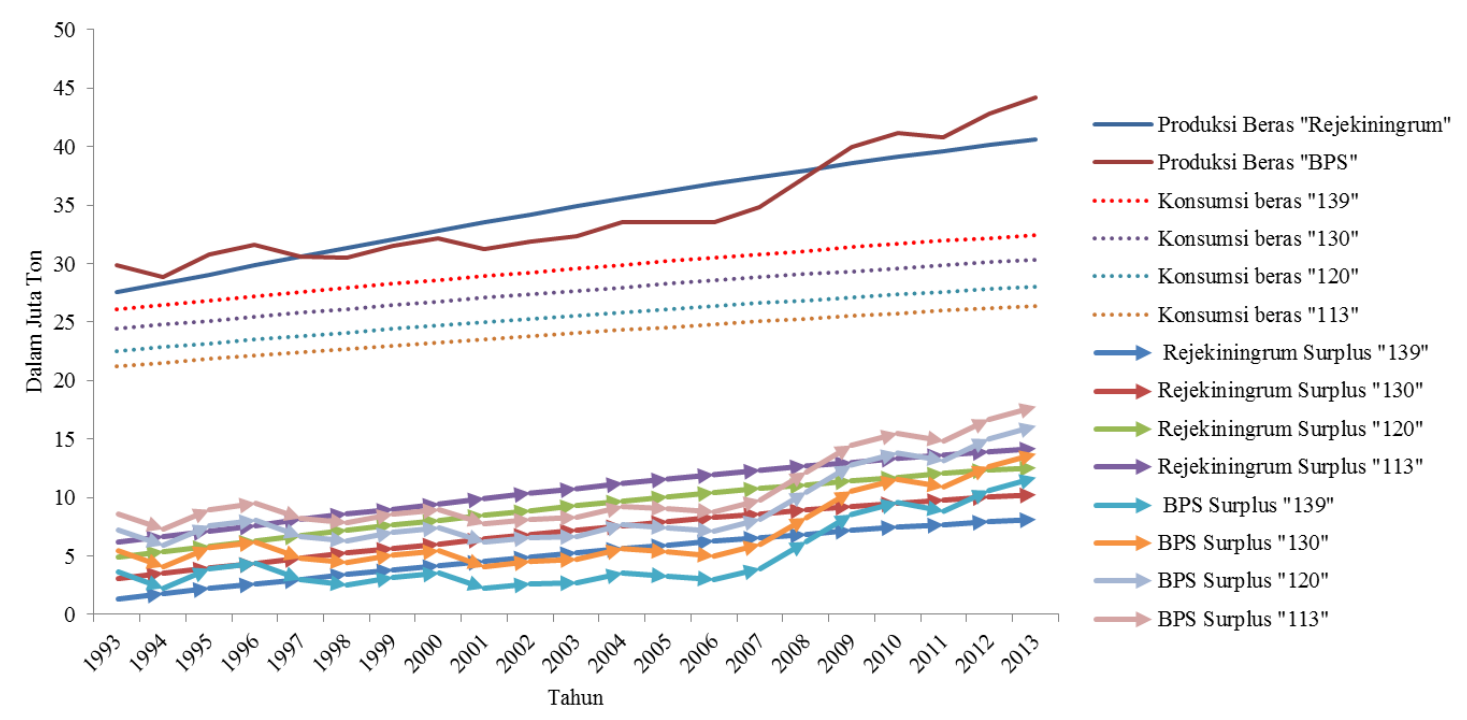

Gambar 4. Produksi, Konsumsi, dan Surplus Beras Indonesia tahun 1990 - 2013209

\section{Dampak Perubahan Iklim Terhadap Tanaman Pangan}

Dampak perubahan iklim global terhadap kondisi iklim wilayah di Indonesia ditandai dengan berubahnya parameter iklim permukaan, yaitu: suhu udara dan curah hujan. Perubahan parameter iklim seringkali ditunjukkan oleh analisis kecenderungan perubahan temporal suhu udara dan curah hujan. Berdasarkan kompilasi informasi analisis kecenderungan dari berbagai sumber, ${ }^{210}$ fenomena perubahan iklim ditandai dengan peningkatan suhu udara rata-rata dan minimum permukaan, perubahan intensitas dan periode kejadian hujan yang bervariasi (Gambar 5).

Fenomena perubahan iklim tersebut memiliki implikasi terhadap produksi tanaman pangan yang bervariasi, yang dikarenakan adanya variasi spasial di Indonesia. Secara umum, suhu udara dilaporkan meningkat, sementara curah hujan mengalami perubahan pola dan besaran yang bervariasi pada berbagai wilayah di Indonesia. Sebagai tambahan, kompilasi berbagai

209 Ibid.

210 Perdinan, Rizaldi Boer, and Kiki Kartikasari. “Linking Climate Change Adaptation Options For Rice Production And Sustainable Development In Indonesia," J.Agromet 22(2), (2008), hlm. 94-107. 
penelitian yang dilakukan di Indonesia menunjukkan adanya potensi dampak negatif perubahan iklim terhadap produktivitas ataupun peningkatan serangan hama dan penyakit (Gambar 6).

produksi padi berupa penurunan

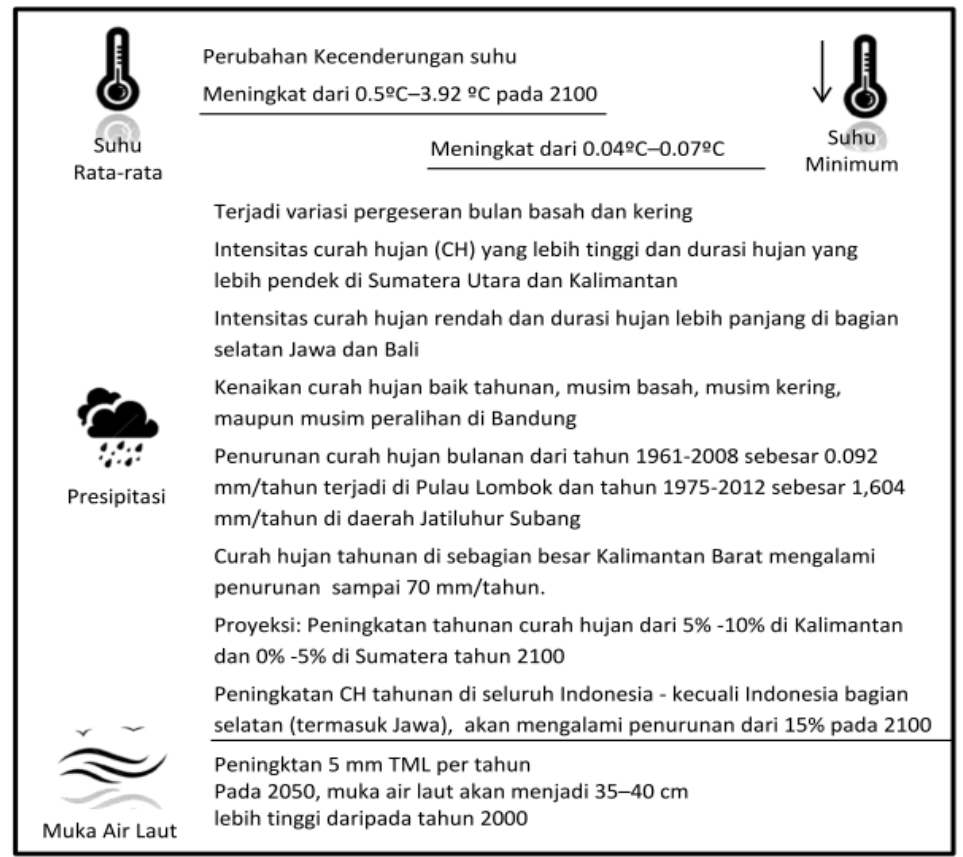

\section{Gambar 5. Identifikasi Dampak Perubahan Iklim Global Terhadap Iklim Wilayah} di Indonesia ${ }^{211}$

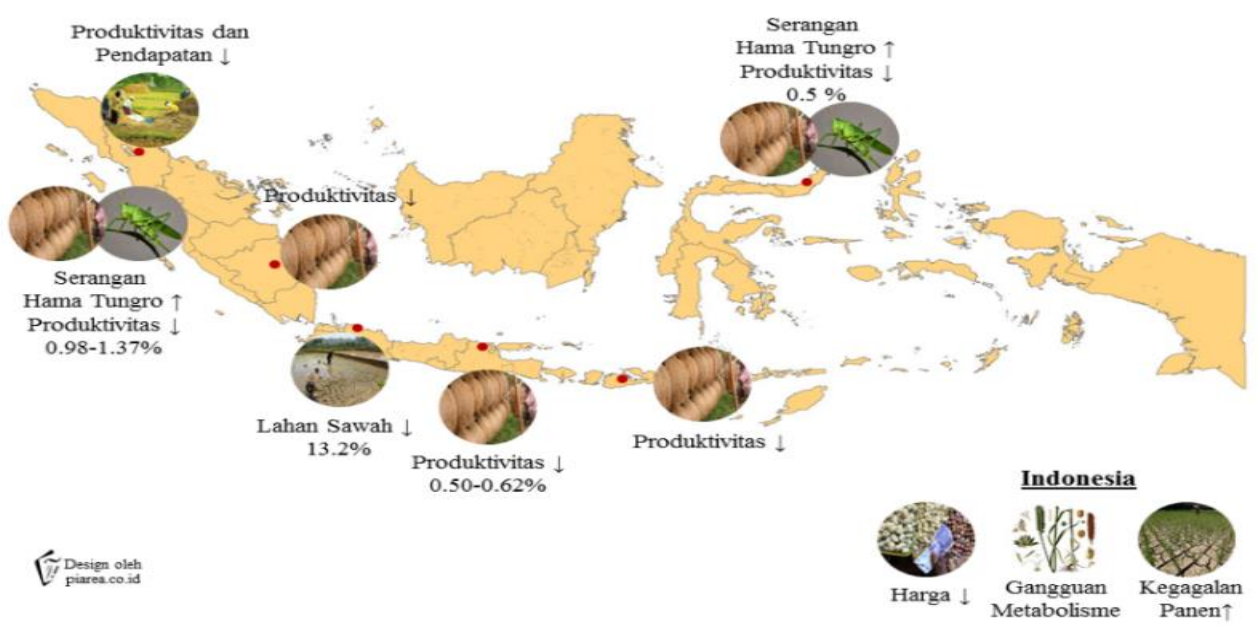

Gambar 6. Identifikasi Dampak Perubahan Iklim terhadap Produksi Padi di Indonesia212

211 Perdinan et. al., "Adaptasi Perubahan Iklim dan Ketahanan Pangan: Telaah Inisiatif dan Kebijakan," (makalah disampaikan pada FGD IESR, 18 Oktober 2016), hlm. 13.

212 Ibid. hlm. 15. 


\section{Inisiatif Adaptasi Perubahan Iklim}

\section{A. Identifikasi Strategi Adaptasi \\ Perubahan Iklim}

Dalam implementasi strategi adaptasi, peran pemerintah sangat diperlukan terutama dalam kegiatankegiatan adaptasi yang memerlukan investasi relatif tinggi. Kegiatan adaptasi tersebut di antaranya: 1) pengembangan dan percepatan adopsi teknologi usaha tani yang lebih produktif dan adaptif terhadap perubahan iklim, 2) penyediaan infrastruktur pertanian yang efektif untuk mendukung aplikasi teknologi adaptif perubahan iklim tersebut, 3) pengembangan jaringan informasi iklim-pertanian, 4) pengembangan kelembagaan perlindungan petani terhadap dampak negatif iklim ekstrem pada usaha tani, dan 5) kebijakan harga masukan dan keluaran usaha tani yang kondusif untuk pendapatan petani. 213

Teknologi adaptasi yang dilakukan dapat berupa: 1) penyesuaian waktu dan pola tanam, 2) penggunaan varietas unggul tahan kekeringan, rendaman, dan salinitas, 3) teknologi panen hujan, dan 4) teknologi irigasi. ${ }^{214}$ Teknologi lain yang dapat diterapkan adalah dengan cara teknologi penanaman Tanpa Olah Tanah (TOT). ${ }^{215}$ Lebih jauh, bentuk adaptasi lainnya terkompilasi pada Gambar 7.

${ }^{213}$ Sumaryanto, "Strategi Peningkatan Kapasitas Adaptasi Petani Tanaman Pangan Menghadapi Perubahan Iklim," Jurnal Forum Penelitian Agro Ekonomi 30 No. 2 (2012), hlm. 73-89.

214 Surmaini, et. al. "Upaya Sektor Pertanian Dalam Menghadapi Perubahan Iklim." Jurnal Litbang Pertanian 30 No. 1, (2010) hlm. 1-7.

215 Zainal Lamid, "Integrasi Pengendalian Gulma dan Teknologi Tanpa Olah Tanah Pada Usaha Tani Padi Sawah Menghadapi Perubahan Iklim," Jurnal Pengembangan Inovasi Pertanian 4 No. 1 (2011), hlm. 14-28. 


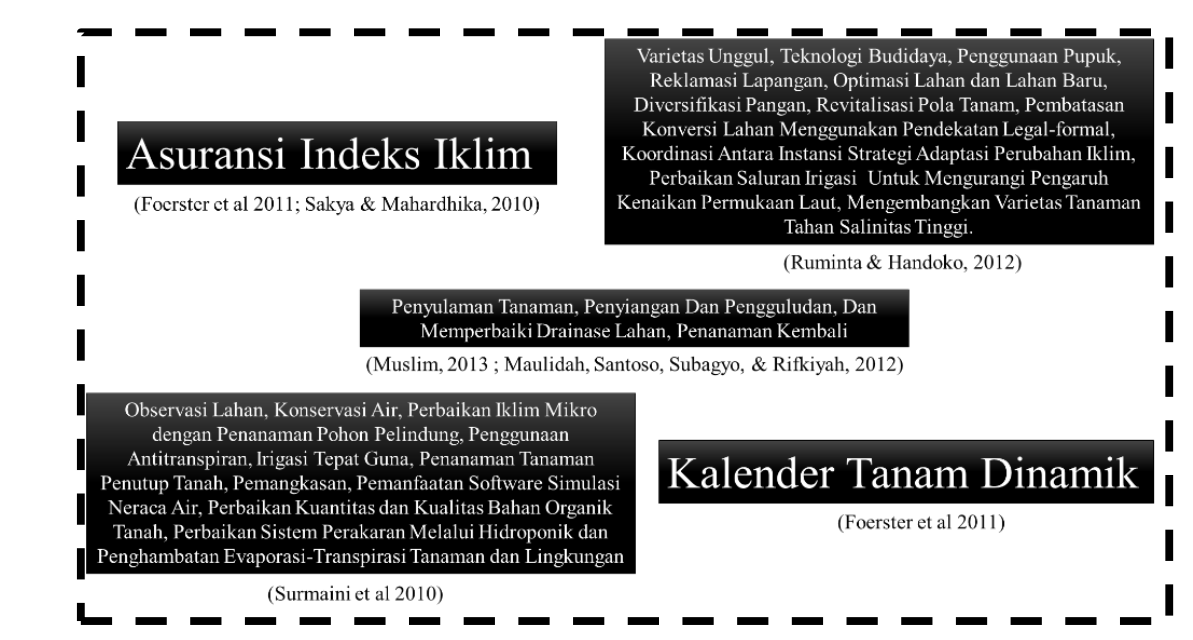

Gambar 7. Hasil Kompilasi Bentuk Adaptasi Perubahan Iklim²16

memberikan bantuan dengan

Kegiatan adaptasi perubahan iklim bila ditilik lebih lanjut dalam tataran praktis, bukanlah hal baru bagi petani di Indonesia. Berdasarkan telaah studi yang dilakukan sebelumnya, ${ }^{217}$ salah satu contohnya adalah sistem pertanaman padi di Indramayu. Petani di Indramayu melakukan penanaman kembali jika memungkinkan, setelah lahan pertanian yang terendam banjir menjadi surut. Dalam kondisi kekeringan, petani akan mencari berbagai sumber air untuk mengairi lahan pertanian. Pompa air sering digunakan untuk mendapatkan air dari tanah atau sungai. Pemerintah juga

216 Surmaini et. al., op. cit.

217 Perdinan, et.al. op. cit. memberikan akses petani ke pompa air.

Pelaksanaan strategi adaptasi untuk pertanian merupakan hal mendasar yang perlu dilakukan baik oleh petani maupun dengan bantuan pihak lain. Namun, kegiatan praktis adaptasi oleh petani seringkali didasarkan oleh nalar dan pengalaman di lapangan, belum disandingkan dengan telaah empiris atau penelitian ilmiah.

Di sisi lain, bantuan pemerintah baik dari segi penelitian ilmiah maupun sarana dan prasarana belum didukung sepenuhnya dengan kapasitas petani. Namun, sejauh ini petani dan pemerintah Indonesia telah 
berusaha dalam memadukan aksi lokal dan strategi nasional sebagai aksi adaptasi pertanian yang terintegrasi. Hal mendasar strategi nasional ini adalah agar pelaksanaannya dapat terstruktur, masif dan tepat sasaran. Peningkatan kapasitas untuk petani juga dilakukan sebagai respon dalam meningkatkan kemampuan adaptasi petani baik dalam merespons perubahan iklim maupun dalam manajemen lahan, hama, dan pestisida. Sebagai contoh antara lain Program Kampung Iklim, Analisis Usaha Tani Padi (AUTP) ataupun program pemahanan informasi iklim seperti Kalender Tanam (Katam). Artinya, program adaptasi yang dilakukan saat ini sudah diarahkan agar dapat lebih efektif dan efisien agar tepat sasaran maupun tepat aksi.

Sebagai contoh, di Indramayu masyarakat telah mulai dapat membaca informasi iklim seperti curah hujan dan dapat menginterpretasikan secara sederhana ketersediaan air dari curah hujan. Demikian juga dengan kalender tanam, pemerintah melalui Kementerian Pertanian dan badan penelitian pertanian terkait telah menyediakan informasi kalender tanam nasional dalam tingkat kecamatan. Manfaat dari informasi ini adalah petani dapat menanam sesuai dengan prediksi cuaca/iklim. Sementara, itu telah terbentuk pula Proklim. Proklim merupakan program yang memberikan pengakuan terhadap partisipasi aktif masyarakat dalam melaksanakan upaya mitigasi dan adaptasi perubahan iklim yang terintegrasi, sehingga dapat mendukung target penurunan emisi gas rumah kaca nasional dan peningkatan ketahanan masyarakat terhadap dampak perubahan iklim. ${ }^{218}$

\section{B. Dukungan Pemerintah Terkait Adaptasi Perubahan Iklim}

Beras merupakan komoditas strategis sebagai bahan pangan utama di Indonesia. Dengan pertimbangan tersebut, pemerintah melakukan berbagai intervensi untuk memenuhi

218 Kurniadi, "Penyusun Bahan Adaptasi Perubahan Iklim BPLHD Provinsi Jawa Barat," (disampaikan di BPLHD Purwakarta, 23 Desember 2013), hlm. 14. 
kebutuhan konsumsi beras nasional. Berbagai program intervensi diarahkan untuk mengoptimalkan produksi beras dan kemampuan para petani. Meskipun program-program terkait peningkatan produksi padi nasional dilakukan jauh sebelum dampak perubahan iklim terhadap produksi tanaman menjadi perhatian, programprogram tersebut terkait dengan fokus kegiatan adaptasi perubahan iklim, yaitu mempertahankan dan/atau meningkatkan produksi.

Dalam Pedoman Umum Balai Penelitian dan Pengembangan Pertanian Tahun 2011, strategi adaptasi diarahkan pada penyesuaian kegiatan dan teknologi terhadap dampak perubahan iklim global melalui program aksi adaptasi pada sektor tanaman pangan dan hortikultura yang menjadi prioritas utama. Sektor tersebut diprioritaskan dengan tujuan untuk mendukung ketahanan pangan nasional.
Strategi adaptasi perubahan iklim untuk sektor pertanian dikategorisasikan secara umum menjadi 2 (dua) kelompok, yaitu: langkah adaptasi yang bersifat struktural dan non-struktural. ${ }^{219}$ Adaptasi struktural merupakan kegiatan peningkatan ketahanan sistem produksi pangan melalui upaya perbaikan kondisi fisik, yang kegiatannya meliputi: pembangunan dan perbaikan jaringan irigasi, pembangunan dam, waduk, dan embung. Sementara, adaptasi nonstruktural dilakukan melalui kegiatan: pengembangan teknologi budidaya toleran cekaman iklim, penguatan kelembagaan dan peraturan, pemberdayaan petani dalam memanfaatkan informasi iklim. Detil kegiatan juga telah dijabarkan dalam Pedum, sebagai berikut:220

1. Adaptasi Struktural

a. Pemetaan kondisi jaringan irigasi dan menyusun program

219 Balai Penelitian dan Pengembangan Pertanian Kementerian Pertanian, Pedoman Umum Adaptasi Perubahan Iklim Sektor Pertanian, (Jakarta: Balai Penelitian dan Pengembangan Pertanian Kementerian Pertanian, 2011), hlm. 24.

220 Ibid. 
rehabilitasi jaringan irigasi di Jawa dan rencana pengembangan wilayah irigasi baru di luar Jawa. Informasi perubahan iklim perlu dipertimbangkan terkait kegiatan jaringan irigasi.

b. Penetapan wilayah Daerah Aliran Sungai (DAS) yang perlu direhabilitasi untuk mengantisipasi dampak negatif kejadian iklim ekstrem (misal: banjir dan kekeringan) yang diproyeksikan meningkat akibat perubahan iklim.

\section{Pendekatan Non-Struktural}

a. Regulasi berkaitan dengan konversi lahan pertanian, penyusunan database wilayah rawan terkonversi, penetapan prioritas wilayah pengembangan pertanian pangan.

b. Penetapan program terstruktur untuk meningkatkan adopsi petani terhadap teknologi baru, seperti varietas unggul baru toleran kekeringan, banjir, dan salinitas tinggi. c. Peningkatan program pengembangan teknologi pemanfaatan informasi iklim seperti "Kalender Tanam" yang lebih bersifat dinamis dan terpadu. Saat ini Kalender Tanam sudah tersedia dan dapat diakses melalui

www.katam.litbang.pertanian.g o.id. Pengembangan sistem jaringan stasiun klimatologi pertanian di kawasan sentra produksi diperlukan untuk meningkatkan sistem Kalender Tanam.

d. Pengembangan Sekolah Lapang Iklim (SLI) dalam upaya peningkatan kapasitas petani dalam memanfaatakn informasi iklim untuk mendukung kegiatan pertanian. Kegiatan SLI sudah dilakukan oleh Kementerian Pertanian (Kementan) melalui Direktorat Perlindungan Tanaman dan Badan Meteorologi Klimatologi dan Geofisika (BMKG) pada tahun 2000-an. 
e. Pelembagaan pemanfaatan informasi iklim dalam menyusun langkah strategis, taktis, dan operasional dalam mengatasi masalah keragaman dan perubahan iklim. Diperlukan alur penyampaian informasi iklim yang jelas, mulai dari penyedia jasa informasi sampai ke pengguna akhir dan penguatan kapasitas tenaga di dinas terkait di daerah dalam menerjemahkan informasi iklim ke dalam bentuk dampak dan penentuan langkah strategis, taktis, dan operasional.

Dalam penyusunan strategi adaptasi diperlukan informasi pendukung. Informasi tersebut disusun berdasarkan beberapa kajian, yaitu: (a) identifikasi dampak dan tingkat kerentanan sektor pertanian (sumber daya dan sistem produksi); (b) identifikasi karakteristik dan potensi sumber daya lahan dan air; dan (c) identifikasi kesiapan teknologi dan model Sistem Usaha tani Terpadu (SUT) adaptif. Sebagai ringkasan berbagai inisiatif yang telah dilakukan pemerintah, berikut ini disajikan berbagai program yang telah dilakukan pemerintah Indonesia sejak tahun 1950an untuk meningkatkan produksi beras nasional (Gambar 8). Berbagai inisiatif ini meliputi adaptasi struktural dan non-struktural. Melalui berbagai kebijakan produksi padi nasional terus meningkat seiring dengan perbaikan produktivitas dan luas areal panen. Peningkatan produksi mencapai puncaknya pada tahun 1984 saat Indonesia berswasembada beras. 


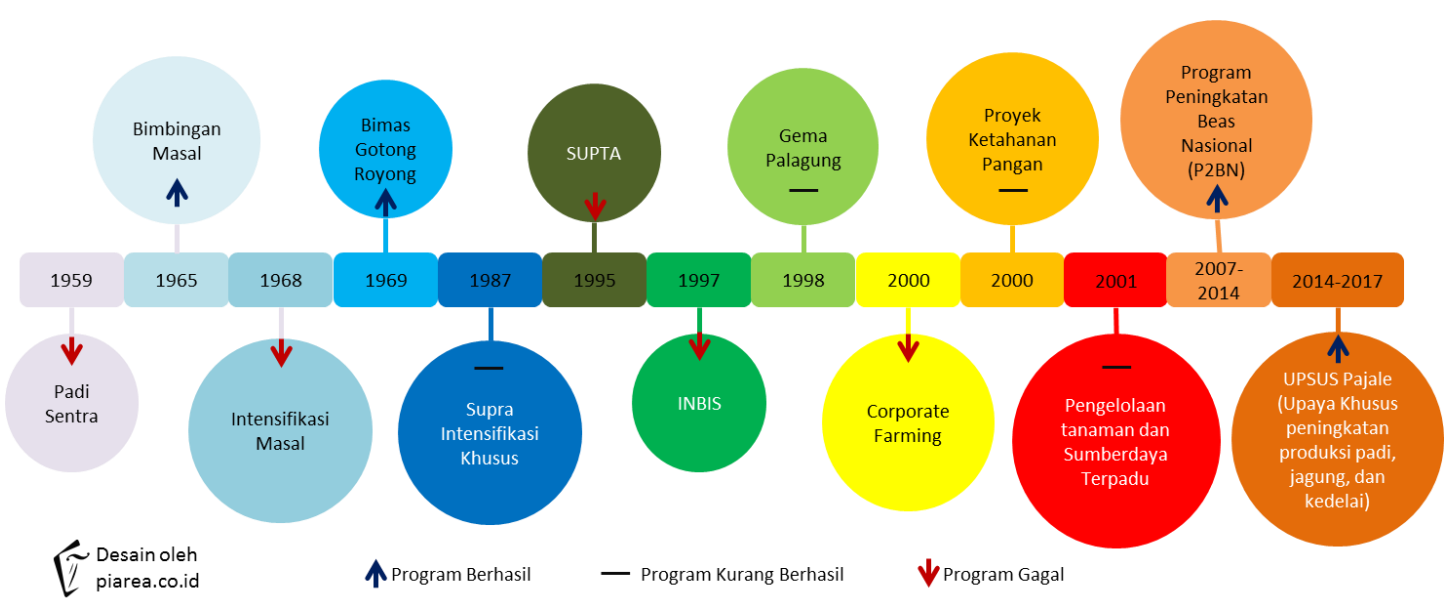

Gambar 8. Program Peningkatan Produksi Padi Nasional dan Paket Teknologi221

C. Kebijakan Nasional dalam dampak adalah potensi kerugian atau

Mendukung Adaptasi Perubahan

Iklim

Adanya fenomena perubahan iklim menambah tantangan sistem pertanian tanaman pangan, khususnya padi di Indonesia. Pengaruh perubahan iklim bersifat multidimensi pada sektor pertanian, mulai dari sumber daya, infrastruktur pertanian, dan sistem produksi pertanian. Pengaruh tersebut dibedakan dengan 2 (dua) indikator, yakni kerentanan dan dampak. Kerentanan merupakan kondisi yang mengurangi kemampuan beradaptasi terhadap perubahan iklim. Sementara, keuntungan dalam bentuk fisik maupun sosial-ekonomi akibat kejadian perubahan iklim. Inisiatif adaptasi perubahan iklim untuk mengurangi kerentanan dan dampak perubahan iklim sektor pertanian terdapat pada Pedum. Adapun program dan kebijakan untuk mengurangi kerentan dan dampak perubahan iklim adalah sebagai berikut:222

1) Pengembangan sistem komunikasi seperti Jaringan Informasi Iklim Pertanian (SJII), Sistem Peringatan Dini (SPD),

221 Perdinan et al, op. cit., hlm. 20.

222 Balai Penelitian dan Pengembangan Pertanian Kementerian Pertanian, op. cit., hlm. 45-50 
dan Sekolah Lapang Iklim (SLI/SL-PTT).

2) Pengembangan kelembagaan petani, penyiapan tool atau pedoman (Permentan No.47/2006, Permentan No.14/2009, UU No.41/2009), blueprint pengelolaan kekeringan dan banjir, atlas kalender tanam, dan lain-lain.

3) Perakitan dan pengembangan model Sistem Usaha tani Terpadu "SUT" dan inovasi teknologi adaptif.

4) Penyesuaian dan pengembangan infrastruktur pertanian (Jaringan Irigasi Tingkat Usaha Tani (JITUT), Jaringan Irigasi Tingkat Desa (Jides), serta pemanfaatan lahan sub-optimal, terutama lahan kering dan lahan rawa untuk pangan, lahan gambut, dan lahan yang sudah dibuka (sudah ada izin) dan/atau lahan terlantar.

5) Pengembangan Kawasan Rumah Pangan Lestari (KRPL), pemanfaatan pekarangan yang ramah lingkungan untuk pemenuhan kebutuhan pangan dan gizi keluarga, serta peningkatan pendapatan dan kesejahteraan petani melalui partisipasi masyarakat.

6) Perlindungan, proteksi, dan bantuan bagi petani, seperti, subsidi, asuransi, modal, Pengembangan Usaha Agribisnis Perdesaan (PUAP).

Kebijakan terkait dukungan terhadap langkah adaptasi perubahan iklim ditujukan untuk menjaga ketahanan pangan nasional. Upaya intervensi dapat dilakukan melalui jaringan produksi, manajemen pascapanen, distribusi, dan konsumsi.

Walaupun demikian, selama ini kebijakan nasional lebih memprioritaskan intervensi pada sektor produksi. Hal ini dikarenakan kondisi petani sebagai pemain utama dalam sektor produksi masih sangat rentan pada cekaman perubahan iklim.

Dalam rangka perlindungan dan pemberdayaan petani untuk menjaga ketahanan pangan maka diterbitkan berbagai aturan sebagai pedoman 
untuk mengatur dan menghadapi kondisi yang ada. Identifikasi kebijakan terkait upaya adaptasi perubahan iklim disajikan pada Gambar 9.
Upaya Peningkatan Kapasitas Petani

UU No.16/2006 Tentang Sistem Penyuluhan Pertanian, Perikanan dan Kehutanan

UU No. 19/2013 Tentang Perlindungan dan Pemberdayaan Petani

ditujukan untuk memberikan arahan guna meningkatkan produktivitas dan kesejahteraan petani. Selain itu pemerintah juga perlu memberikan infomasi untuk mengantisipasi terjadinya kegagalan panen. Salah satunya adalah prakiraan iklim.
UU No.19/2013 mengatur beberapa bentuk antisipasi pada kondisi perubahan iklim. Pada pasal 7 (2) poin $\mathrm{f}$, strategi perlindungan petani melalui sistem peringatan dini dan penangan dampak perubahan iklim. Pada pasal 34, Pemerintah dan Pemda sesuai dengan kewenangannya membangun sistem peringatan dini dan penanganan dampak perubahan iklim untuk mengantisipasi gagal panen akibat bencana alam. Pada pasal 35,1$)$ pemerintah wajib melakukan prakiraan iklim untuk mengantisipasi terjadinya kegagalan panen, 2) pemerintah wajib mengantisipasi terjadinya kegagalan panen dengan melakukan: a. peramalan serangan OPT,serangan hama, dan atau wabah penyakit hewan menular b. upaya penanganan terhadap hasil prakiraan iklim dan peramalan serangan OPT.

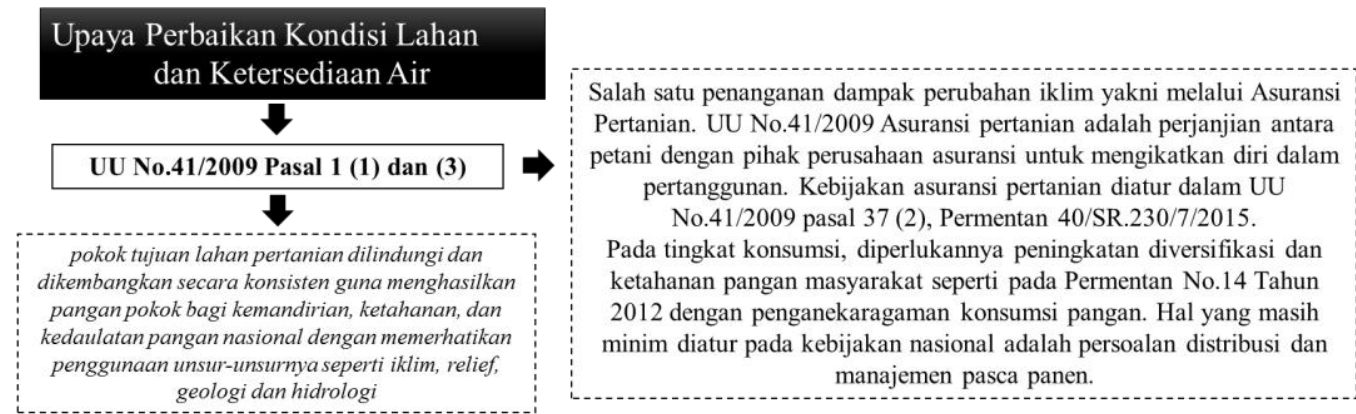

Gambar 9. Identifikasi kebijakan sektor pertanian terkait adaptasi perubahan iklim 223

Selanjutnya berbagai kebijakan adaptasi perubahan iklim yang didorong pemerintah terfokus pada peningkatan kapasitas petani dan infrastruktur pertanian. Salah satu kebijakan yang mendukung hal tersebut adalah Peraturan Menteri Lingkungan Hidup dan Kehutanan (Permen LHK) No. 33 Tahun 2016 tentang Pedoman Penyusunan Aksi Adaptasi Perubahan Iklim.

Peraturan tersebut memuat arahan dalam pelaksanaan adaptasi perubahan iklim secara umum sebagai proses untuk memperkuat dan membangun strategi antisipasi dampak perubahan iklim pada wilayah dan sektor spesifik termasuk pertanian. Peraturan tersebut juga memberikan

${ }^{223}$ Indonesia, Undang-Undang Sistem Penyuluhan Pertanian, Perikanan, dan Kehutanan, UU No. 16 Tahun 2006, LN No. 92 tahun 2006, TLN No.4660. lihat juga Indonesia, Undang-Undang Perlindungan dan Pemberdayaan Petani, UU No. 19 Tahun 2013, LN No. 131 tahun 2013, TLN No. 5433, Ps. 7 ayat (2) huruf f, Ps. 34, dan Ps. 35. Dan lihat Indonesia, Undang-Undang Kehutanan, UU No. 41 Tahun 2009, LN No. 167 Tahun 1999, TLN No.3888, Ps. 1 ayat (1) dan (3), Ps. 37 ayat (2). 
arahan rinci terkait kebutuhan dalam tahapan pelaksanaan penyusunan aksi adaptasi sebagaimana telah dituliskan pada Pasal 4 yang berisi: 1) Identifikasi target cakupan wilayah dan/atau sektor spesifik dan masalah dampak perubahan iklim; 2) Penyusunan kajian kerentanan dan risiko iklim; 3) Penyusunan pilihan aksi adaptasi perubahan iklim; 4) Penetapan prioritas aksi adaptasi perubahan iklim; dan 5) Pengintegrasian aksi adaptasi perubahan iklim ke dalam kebijakan, rencana, dan/atau program pembangunan. Adanya tahapan tersebut mempermudah penyusunan aksi adaptasi perubahan iklim.

Dukungan kebijakan adaptasi perubahan iklim secara umum lebih ditujukan pada arahan jangka menengah, dengan fokus utamanya adalah meningkatkan dan menguatkan beberapa aspek seperti kapasitas lokal dan pengelolaan pengetahuan.224 Arahan kebijakan mengenai konvergensi adaptasi perubahan iklim dan pengurangan risiko bencana juga menjadi aspek penting yang perlu diprioritaskan, dengan pertimbangan kondisi ketahanan pangan saat ini juga rentan terhadap potensi bencana yang muncul akibat perubahan iklim. Implementasi dari kebijakan yang dilakukan mendorong penerapan teknologi adaptif yang mampu meminimalisasi potensi dampak negatif perubahan iklim terutama yang berkaitan dengan penurunan risiko pada semua sektor pembangunan (pertanian, sumber daya air, ketahanan energi, kehutanan, maritim dan perikanan, kesehatan, pelayanan publik, infrastruktur dan sistem perkotaan).

Kebijakan yang diterbitkan oleh Kementerian Lingkungan Hidup dan Kehutanan (KLHK) di atas (Permen 33/2016) telah sejalan dengan Kementerian Pertanian melalui Direktorat Perlindungan Tanaman Pangan dengan diterbitkannya Petunjuk Teknis Pelaksanaan

${ }^{224}$ Direktur Adaptasi Direktorat Jenderal Pengendalian Perubahan Iklim Kementerian Lingkungan dan Kehutanan, "Arah Kebijakan dan Sasaran Adaptasi Perubahan Iklim di Indonesia," (disampaikan di Jakarta, 26-27 April 2018), hlm. 15-19. 
Penerapan Penanganan Dampak Perubahan Iklim (PPDPI) pada tahun 2018.

PPDPI bertujuan memberdayakan petani dalam pengamanan areal pertanaman padi dari dampak perubahan iklim melalui penerapan teknologi adaptif di lahan usaha taninya, terutama pada daerah yang rawan terkena banjir/kekeringan serta mengurangi risiko kehilangan hasil akibat dampak perubahan iklim (banjir/kekeringan). ${ }^{225}$

\section{Penutup}

Walaupun berbagai upaya peningkatan produksi padi domestik sudah dilakukan sejak awal tahun 1950-an dan pemerintah melalui Kementan juga telah menerbitkan Pedum, tetap terdapat tantangan untuk meningkatkan produksi padi domestik mengingat potensi dampak perubahan iklim. Persoalannya saat ini adalah bagaimana implementasi Pedum tersebut dapat direncanakan sesuai kebutuhan dan dilakukan oleh para petani.

Pedum sektor pertanian ini ditujukan untuk memberikan arahan dan meningkatkan pemahaman dalam mengidentifikasi dampak perubahan iklim sekaligus mendorong dan mengarahkan upaya dan program aksi adaptasi pertanian untuk mengurangi atau memanfaatkan variabilitas dan dampak perubahan iklim baik dalam bentuk struktural maupun nonstruktural.

Dalam perjalanannya, Pedum ini mendapat respons yang sangat baik dari tataran pemerintah selaku pemangku kewenangan maupun petani sebagai pelaksana. Lebih lanjut, permen LHK No.33 Tahun 2016 yang memuat arahan pelaksanaan adaptasi perubahan iklim merupakan kebijakan pendukung pelaksanaan Pedum tersebut. Kedua kebijakan saling relevan dan berkesinambungan. Pada dasarnya pelaksanaan adaptasi secara luas dapat mengikuti arahan kebijakan

${ }^{225}$ Direktorat Perlindungan Tanaman Pangan Kementerian Pertanian, Petunjuk Teknis Pelaksanaan Penerapan Penanganan Dampak Perubahan Iklim, (Jakarta: Direktorat Perlindungan Tanaman Pangan Kementerian Pertanian, 2018), hlm. 1-5. 
Permen LHK 33/2016, sementara Pedum menjabarkan upaya adaptasi pada sektor pertanian secara khusus. Secara terarah strategi adaptasi yang terdapat pada Pedum dapat dilakukan mengikuti arahan pada Permen LHK $33 / 2016$.

Sementara pada tataran pelaksana, petani terbantu dengan adanya dukungan insfrastruktur maupun kebijakan daerah. Pelaksanaan Pedum ini sebagai contoh seperti yang dilakukan di daerah Jawa Barat dengan studi kasus di Indramayu melalui pelaksanaan Sekolah Lapang Iklim dan pemanfaatan Kalender Tanam Terpadu. Pada praktiknya petani terbantu dalam memahami informasi iklim dan mengantisipasi kejadian iklim ekstrem, mengamati unsur iklim, dan menggunakannya dalam mendukung usaha tani, serta terbantu dalam menerjemahkan informasi prakiraan iklim untuk menyusun strategi budidaya lebih tepat.

Meskipun demikian, implementasi Pedum tidaklah mudah. Tantangan yang ditemukan dalam pelaksanaan adaptasi perubahan iklim sektor pertanian sekaligus dalam implementasi Pedum di atas adalah adanya kesenjangan kapasitas petani dan insfratruktur pendukung pelaksanaan adaptasi tersebut. Ketersediaan perlengkapan sarana pembelajaran yang kurang memadai dan minimnya pengetahuan petani membuat proses implementasi berjalan lambat.

Selain itu, terdapat kesenjangan antara pembuat informasi iklim (BMKG) dengan permintaan pengguna di sektor pertanian dan pembuat kebijakan. Informasi prediksi onset atau awal musim tidak segera diperoleh pengguna akibat keterbatasan akses dan kurangnya pemahaman atau interpretasi informasi. Meskipun demikian, beberapa informasi iklim sudah tersedia walaupun belum maksimal. Hal ini mengharuskan adanya langkah-langkah yang koordinatif dan kooperatif dengan berbagai pengguna infomasi iklim/perubahan iklim yang akan memberikan hasil yang menguntungkan untuk semua pihak khususnya untuk sektor pertanian. 
Dalam upaya mendukung dan menjawab tantangan tersebut terutama dalam pelaksanaan adaptasi, ketersediaan data dan informasi serta ketersediaan alat simulasi dan sistem pendukungnya diperlukan untuk perencanaan aksi adaptasi dalam skala luas. Tantangan lain adalah pengetahuan petani dan akses terhadap lembaga keuangan yang relatif masih terbatas. Contohnya, pengetahuan petani mengenai Katam berbasis web agak terhambat karena pendidikan petani yang kurang, sehingga diperlukan peran serta penyuluh yang andal yang memahami kalendar tanam dan dapat menerjemahkan sesuai kebutuhan petani. Upaya pemerintah untuk mendukung petani padi terhadap pengenalan varietas baru sebagai salah satu pilihan adaptasi juga masih perlu ditingkatkan, misalnya: dalam kebijakan terkait bantuan benih. Pemerintah juga perlu mempertimbangkan suplai benih unggul dengan mempromosikan inventor lokal dari daerah asal sentra produksi padi.
Lebih lanjut, keterlibatan pemerintah dalam kegiatan peningkatan kapasitas petani perlu diteruskan. Kegiatan peningkatan kapasitas dapat dilakukan melalui pelatihan/workshop, contohnya dalam pengenalan varietas baru, teknologi, dan kegiatan pascapanen. Selanjutnya, ketersediaan lembaga keuangan dan akses petani terhadap bantuan modal untuk mengakses sarana pertanian juga dapat dilakukan untuk mempromosikan pilihan adaptasi. Misalnya tersedianya informasi manajemen pertanian (dosis pemupukan dan jenis pupuk, sistem pertanaman, pengairan) yang sesuai kondisi iklim, sebagai bagian dari bantuan permodalan. Skema akses permodalan tersebut perlu dibangun melalui kerjasama dengan lembaga keuangan mikro dalam upaya mendukung inisiatif kemitraan dan kerjasama berbagai pihak agar target ketahanan pangan nasional dapat terwujud.

Arahan ke depan, proses dan implementasi Pedum memerlukan upaya yang sistematis dan terintegrasi 
dengan strategi yang andal, serta komitmen, dan tanggung jawab bersama dari berbagai pemangku kepentingan dan para pihak. Selain itu, untuk dapat menjaga keberlanjutan implementasi di lapangan, susunan strategi atau pilihan adaptasi perlu disediakan sebagai pilihan. Di samping itu, rekomendasi adaptasi yang disediakan untuk daerah pertanian juga perlu disesuaikan dengan kapasitas dan kondisi lokal. Kesesuaian dan kesiapan daerah perlu menjadi pertimbangan, dikarenakan beda daerah akan beda perlakuan dan pemahaman, serta adanya variasi dalam ketersediaan sarana pendukung. 
DAFTAR PUSTAKA

\section{Peraturan Perundang-Undangan}

Indonesia,

Undang-Undang

Kehutanan, UU No. 41 Tahun 1999, LN No. 167 Tahun 1999, TLN No.3888.

_ Undang-Undang Sistem Penyuluhan Pertanian, Perikanan, dan Kehutanan, UU No. 16 Tahun 2006, LN No. 92 tahun 2006, TLN No.4660.

Undang-Undang Perlindungan dan Pemberdayaan Petani, UU No. 19 Tahun 2013, LN No. 131 tahun 2013, TLN No. 5433.

\section{Buku}

Balai Penelitian dan Pengembangan Pertanian Kementerian Pertanian. Pedoman Umum Adaptasi Perubahan Iklim Sektor Pertanian. Jakarta: Balai Penelitian dan Pengembangan Pertanian Kementerian Pertanian. 2011.

Direktorat Perlindungan Tanaman Pangan Kementerian Pertanian. Petunjuk Teknis Pelaksanaan Penerapan Penanganan Dampak
Perubahan Iklim. Jakarta:

Direktorat Perlindungan

Tanaman Pangan Kementerian

Pertanian. 2018.

Ministry of Environment. Climate risk dan adaptation assessment for the agriculture sector-Greater Malang. Jakarta: Ministry of Environment. 2012.

Prasada Rao, G. S. L. H. V. Agricultural Meteorology. Thrissur: PHI Learning Pvt. Ltd. 2008.

\section{Artikel}

Cline, William. "Global Warming and Agriculture: Impact Estimates by Country". Choice Reviews Online 45, No. 04 (2007): 45-213545-2135.

Förster, Hannah, et.al. "Sea-Level Rise in Indonesia: on Adaptation Priorities in The Agricultural Sector". Regional Environmental Change 11, No. 4 (2011). hlm. 893 904.

Hoogenboom, Gerrit. "Contribution of Agrometeorology to The Simulation of Crop Production and Its 
Applications". Agricultural and

Forest Meteorology 103, No. 1-2 (2000): 137-157.

Hosang, Peter Rene, J. Tatuh, dan

Johannes E. X. Rogi. 2012.

"Analisis Dampak Perubahan

Iklim Terhadap Produksi Beras

Provinsi Sulawesi Utara Tahun

2013-2030." Jurnal Eugenia no.

Volume 18 No. (3) (2012). Hlm.

249-256.

Lamid, Zainal. “Integrasi Pengendalian

Gulma dan Teknologi Tanpa

Olah Tanah Pada Usaha Tani

Padi Sawah Menghadapi

Perubahan Iklim." Jurnal

Pengembangan Inovasi Pertanian 4

No. 1 (2011). Hlm. 14-28.

Motha, Raymond P., and Wolfgang

Baier. "Impacts of Present and

Future Climate Change and

Climate Variability on

Agriculture in The Temperate

Regions: North

America". Climatic Change 70,

No. 1-2 (2005): 137-164.

Muslim, C. Mitigasi Perubahan Iklim

Dalam Mempertahankan

Produktivitas Tanah Padi Sawah
(Studi Kasus Di Kabupaten Indramayu). Jurnal Penelitian Pertanian Terapan, Vol. 13 No. 3 (2013). hlm. 211-222.

Kementerian Pertanian. "Buletin Konsumsi Pangan." Vol. 9 No. 1 Tahun 2018.

Perdinan, Kiki Kartikasari, and Marissa Malahayati. "Linking Climate Change Adaptation Options For Rice Production and Sustainable Development In Indonesia." J.Agromet 22(2). (2008).

Sumaryanto. "Strategi Peningkatan Kapasitas Adaptasi Petani Tanaman Pangan Menghadapi Perubahan Iklim." Jurnal Forum Penelitian Agro Ekonomi 30 No. 2 (2012). hlm. 73-89.

Surmaini, et. al. "Upaya Sektor Pertanian Dalam Menghadapi Perubahan Iklim." Jurnal Litbang Pertanian 30 No. 1, (2010). hlm. 17.

Timmermann, A. et al. "Increased El Niño Frequency in A Climate Model Forced by Future Greenhouse 
Warming." Nature 398. No. 6729 (1999): hlm. 694-697.

Tubiello, F. N., J.-F. Soussana, and S. M. Howden. "Crop and Pasture Response to Climate Change". Proceedings of The National Academy of Sciences 104, No. 50 (2007): 19686-19690.

\section{Lain-Lain}

Badan Pusat Statistik (BPS). “Tanaman Padi Per Provinsi." https://www.bps.go.id/site/re sultTab. diakses 3 September 2018.

Direktur Adaptasi Direktorat Jenderal Pengendalian Perubahan Iklim Kementerian Lingkungan dan Kehutanan. “Arah Kebijakan dan Sasaran Adaptasi Perubahan Iklim di Indonesia." (disampaikan di Jakarta, 26-27 April 2018).

Kurniadi. "Penyusun Bahan Adaptasi Perubahan Iklim BPLHD Provinsi Jawa Barat." (disampaikan di BPLHD Purwakarta, 23 Desember 2013).
Perdinan et. al., “Crop Insurance Based on Weather Index for Climate Risk Management in Indonesia." CCROM. 2015.

. “Adaptasi Perubahan Iklim dan Ketahanan Pangan: Telaah Inisiatif dan Kebijakan." (makalah disampaikan pada FGD IESR, 18 Oktober 2016).

Pratiwi, Purdiyanti. "Efektivitas dan Perumusan Strategi Kebijakan Beras Nasional." Bogor: Departemen Agribisnis, Institut Pertanian Bogor. 2008.

Rejekiningrum, Popi, Model Optimasi Surplus Beras Untuk Menentukan Tingkat Ketahanan Pangan Nasional. Jakarta: Universitas Terbuka. 2013.

Simatupang P. dan I.W. Rusastra. “Kebijakan Pembangunan Sistem Agribisnis Padi dalam Ekonomi Padi dan Beras Indonesia." Jakarta: Badan Penelitian dan Pengembangan Pertanian, Departemen Pertanian. 2004. 